\section{Спортивная МеАИцина:}

DOI: 10.17238/ISSN2223-2524.2017.2

\section{РУБРИКИ ЖУРНАЛА:}

- Физиология и биохимия спорта

- Спортивное питание

- Фармакологическая поддержка

- Антидопинговое обеспечение

- Неотложные состояния

- Реабилитация

- Функциональная диагностика

- Биомедицинские технологии

- Спортивная гигиена

- Спортивная травматология

- Спортивная психология

- Социология и педагогика в спорте

- Организация тренировочного процесса

- Врачебный контроль

- Паралимпийский спорт

- Медицинское сопровождение ветеранов спорта

- Организация медицины спорта

- Резолюции конференций и интервью

- Медицинское образование

- Новости

- Памятные даты

\section{Виды публикуемых материалов:}

- Оригинальные статьи

- Обзоры литературы

- Лекции

- Клинические наблюдения, случаи из практики

- Комментарии специалистов

\section{Издатель:}

ООО Издательский дом

«Русский врач»

119270, Россия, г. Москва

ул. 3-я Фрунзенская, д. 6

Тел.: +7 (499) 248-08-21

E-mail: info@rusvrach.ru

Заведующая редакцией журнала:

Иовлева Александра Дмитриевна

Тел.: +7 (963) 630-95-30

E-mail: info@smjournal.ru

Отдел подписки:

Самойлов Геннадий Борисович

Тел.: +7 (905) 702-45-32

E-mail: podpiska@rusvrach.ru Отдел рекламы:

Данилова Надежда Григорьевна

Тел.: +7 (915) 313-32-22

E-mail:pr-median@ya.ru

$$
\text { Сайт: }
$$

www.smjournal.ru

www.rusvrach.ru

Подписано в печать 01.06.2017

Формат 60х90/8

Тираж 1000 экз.

Цена договорная

Свидетельство о регистрации средства массовой информации ПИ № ФС7743704 от 24 января 2011 г.

Журнал включен ВАК в Перечень российских рецензируемых научных журналов, в которых должны быть опубликованы основные научные результаты диссертаций на соискание ученых степеней доктора и кандидата наук.

Плата за публикацию статей в журнале с аспирантов не взимается. Перепечатка опубликованных в журнале материалов допускается только с разрешения редакции. При использовании материалов ссылка на журнал обязательна. Присланные материалы не возвращаются.Точка зрения авторов может не совпадать с мнением редакции.Редакция не несет ответственности за достоверность рекламной информации.

Подписной индекс в каталоге «Пресса России» 90998

\title{
СОДЕРЖАНИЕ
}

Физиология и биохимия спорта

Н. А. Фудин, С. Я. Классина, Ю. Е. Вагин, С. Н. Пигарева

Влияние произвольного гиповентиляционного дыхания на функциональное состояние и физическую работоспособность человека при различных по интенсивности режимах

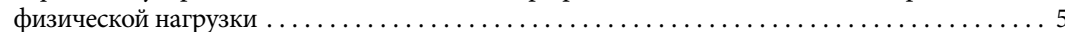

Функциональная диагностика

С. Ф. Задворьев, О. Б. Крысюк, А. Г. Обрезан

Показатели перегрузки сердца и его ремоделирования у представителей

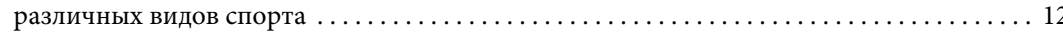

А. Е. Чиков, Д. С. Медведев

Механизмы энергообеспечения мышечной деятельности при выполнении

стандартизированных нагрузок спортсменов . . . . . . . . . . . . . . . . . . . 19

\section{Реабилитация}

А. С. Могельницкий, О. Ю. Павлова, О. В. Кучинская

Функциональные нарушения мышечного тонуса и их коррекция

методом динамической мышечно-фасциальной мобилизации у спортсменов $\ldots \ldots \ldots \ldots 25$

С. И. Гончарова, Н. А. Шнайдер, Д. В. Дмитриенко

Лечебная физкультура и стрейч-терапия в комплексном лечении

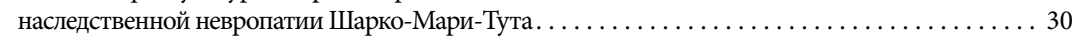

Спортивное питание

С. А. Колесов, Р. С. Рахманов, Т. В. Блинова, Л. А. Страхова, Н. В. Чумаков, Ю. Г. Пискарев Особенности функционирования системы глутатиона при физических нагрузках

и влияние на нее алиментарных факторов .......................... 39

К. Н. Наумова, Б. М. Кершенгольи, В. В. Аньшакова, Р. И. Платонова

Коррекция функционального состояния организма спортсменов с помощью

биопрепаратов растительного происхождения - сорбентов эндотоксинов $\ldots \ldots \ldots \ldots 46$

Т. А. Пушкина, Т. С. Попова, А. В. Жолинский, А. В. Дмитриев, Э. С. Токаев,

М. С. Ключников, А. Е. Шестопалов

Пептиды L-Глутамина как средство ускоренной регидратации

при интенсивных физических нагрузках у спортсменов ....

Спортивная гигиена

Р. Т. Камилова, З. Ф. Мавлянова, Л. И. Исакова, И. А. Шарафова

Сравнительная оценка показателей силовых индексов ведущей руки

и спины среди детей Узбекистана, занимающихся различными группами видов спорта . . . 61

О. С. Лариниева

Неотложные состояния

К вопросу о внезапной сердечной смерти у спортсменов:

анализ литературы за 2016 год . . . . . . . . . . . . . .

Врачебный контроль

Е. В. Харламов, С. В. Орлова, О. В. Дойчева, Е. В. Осипов, О. А. Аксенова

Анализ физической подготовленности студентов согласно нормам

Всероссийского физкультурно-спортивного комплекса «Готов к труду и обороне»

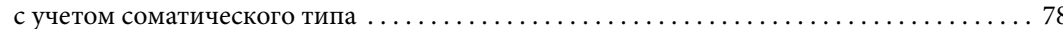

\section{Антидопинговое обеспечение}

А. С. Оганесян, А. А. Саакян, Дж. Джалле, Р. Донован

Исследование социальных переменных, связанных с использованием допинга

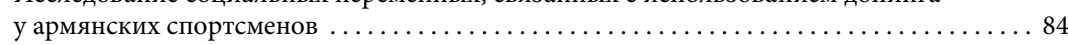

\section{Медицинское образование}

И. Э. Есауленко, В. А. Решетников, Т. Н. Петрова, В. И. Попов, В. В. Михайловский Оценка эффективности инновационных форм формирования здорового образа жизни студентов в ходе реализации здоровьесберегающего проекта. . . . . . . . . 90 Организация медицины спорта

Г. А. Макарова, Л. Н. Порубайко, С. Ю. Юрвев

Система допуска к занятиям спортом: направления совершенствования . $\ldots \ldots \ldots \ldots \ldots 98$

Журнал включен в российские и международные библиотечные и реферативные базы данных

\section{eLIBRARY.RU}

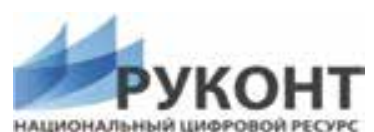

НАцИОНАЛЬНЫЙ ЧИФРОВОЙ РЕСУРС

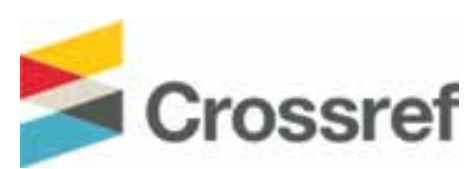

ULRICHSWEB"

GLOBAL SERIALS DIRECTORY

INFOBASE INDEX

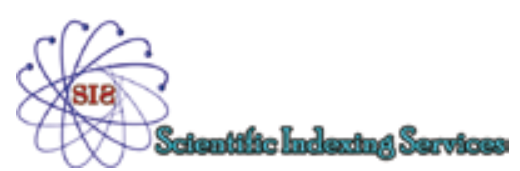


Sports

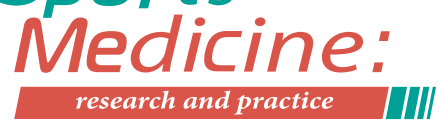

DOI: 10.17238/ISSN2223-2524.2017.2

FEATURED TOPICS:

- Sports Physiology and Biochemistry

- Sports Supplements

- Sports Pharmacology

- Doping Studies

- Prehospital Care and Emergency Medicine

- Rehabilitation

- Functional Testing

- Biomedical Technologies

- Sports Hygiene

- Sports Traumatology

- Sports Psychology

- Sports Sociology and Pedagogics

- Organization of Training Process

- Medical Control

- Paralympic Sports

- Medical Care for Retired Athletes

- Sports Medicine Management

- Sports Medicine Conferences Digest and Interviews

- Medical Education

- News

- Anniversaries and Memorable Days TYPES OF PUBLISHED MATERIALS:

- Original Research

- Articles Review

- Lectures

- Clinical Cases

- Editorials

\section{Publisher:}

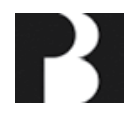

«Russkiy Vrach»

Publishing House

6 - 3d Frunzenskaya St., Moscow, Russia 119270

Phone: +7 (499) 248-08-21

E-mail: info@rusvrach.ru

Aleksandra Iovleva

Managing editor:

Mobile: +7 (963) 630-95-30

E-mail: info@smjournal.ru

Gennadiy Samoylov

Subscription department:

Mobile: +7 (905) 702-45-32

E-mail: podpiska@rusvrach.ru

Advertising department:

Nadezhda Danilova

Mobile: +7 (915) 313-32-22

E-mail: pr-median@ya.ru Websites:

www.smjournal.ru

www.rusvrach.ru

Subscribed into printing 01.06.2017

60x90/8 Format

1000 Copies

Media Outlet Registration Certificate PI № FS77-43704; Jan 24, 2011.

The Journal is included in the list of Russian reviewed scientific journals of the Higher Attestation Commission for publication of main results of Ph.D and D.Sc research.

There is no publication fee for postgraduate students.

Overprinting of published in the journal materials is prohibited without permission of chief editor. In use of the materials the reference to journal is obligatory. Received papers and other materials are not subject to be returned. The authors view point may not coincide with editorial opinion. Editorial office is not responsible for accuracy of advertising information.

«Russian Press» catalog index 90998

\section{CONTENTS}

Sports Physiology and Biochemistry

N. A. Fudin, S. Ya. Klassina, Yu. E. Vagin, S. N. Pigareva

Influence of voluntary hypoventilation breathing on the functional state and physical

working capacity of a person at different intensity regimes of physical load $\ldots \ldots \ldots \ldots \ldots 5$

Functional Testing

S. F. Zadvorev, O. B. Krysiuk, A. G. Obrezan

Markers of cardiac overload and its remodeling in athletes representing different sports . . . . . 12 A. E. Chikov, D. S. Medvedev

Energy supply of athletes' muscles at the performance of standardized loads . . . . . . 19

Rehabilitation

\section{A. S. Mogelnitskiy, O. Yu. Pavlova, O. V. Kuchinskaya}

Functional disorders of muscle tone and its correction by the method

of dynamic musculofascial mobilization in athletes. . . .

S. I. Goncharova, N. A. Shnayder, D. V. Dmitrienko

Exercise and stretch therapy in the complex treatment of Charcot-Marie-Tooth

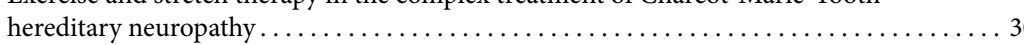

Sports Supplements

S. A. Kolesov, R.S. Rakhmanov, T. V. Blinova, L. A. Strakhova, N. V., Chumakov,

Yu. G. Piskarev

Gluthatione system during physical loads and alimentary factor impact on it $\ldots \ldots \ldots 39$

K. N. Naumova, B. M. Kershengoltz, V. V. Anshakova, R. I. Platonova

Correction of a functional condition of athletes with herbal medicines -

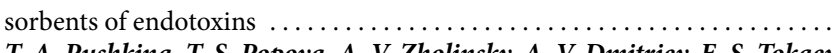

T. A. Pushkina, T. S. Popova, A. V. Zholinsky, A. V. Dmitriev, E. S. Tokaev,

M. S. Klyuchnikov, A. E. Shestopalov

L-Glutamine peptides as a means of accelerated rehydration under intense

physical activity in athletes...

\section{Sports Hygiene}

R. T. Kamilova, Z. F. Mavlyanova, L. I. Isakova, I. A. Sharafova

Comparative assessment of strength indexes indicators of the leading hand

and back among children of Uzbekistan engaged in different sports groups

O. S. Larintseva

Prehospital Care and Emergency Medicine

Sudden cardiac death in athletes: literature review of 2016

\section{Medical Control}

E. V. Kharlamov, S. V. Orlova, O. V. Doycheva, E. V.Osipov, O. A. Aksenova

Analysis of the physical fitness of students in accordance with the norms of the All-Russian

sports complex «Ready for labor and defense» with regard to somatic type......... 78

Doping Studies

A. S. Hovhannisyan, A. A. Sahakyan, G. Jalleh, R. Donovan

Investigation of social variables associated with the use of doping among

Armenian athletes

Medical Education

I. E. Yesaulenko, V. A. Reshetnikov, T. N. Petrova, I. V. Popov, V. V. Mikhaylovskiy Evaluation of the efficiency of innovative forms of healthy lifestyle of students during

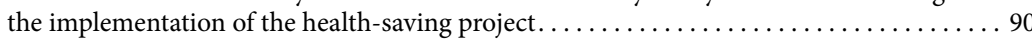
Organization of Training Process

G. A. Makarova, L. N. Porubayko, S. Y. Yurev

Medical clearance for participation in sports: the way to improvements $\ldots \ldots \ldots \ldots \ldots \ldots . \ldots 8$

The Journal is included in Russian and International Library and Abstract Databases:

CLIBRARY,RU

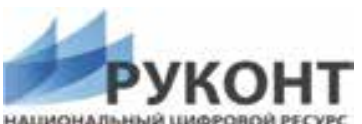

Crossef
(1) ULRICHSWEB"

INFOBASE INDEX

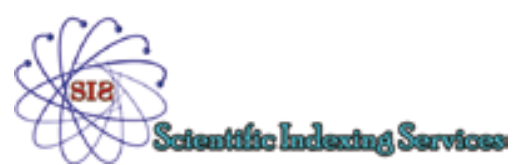

